\title{
Petrography and Geochemistry of some Granitoids associated with Gold Mineralisation at Mpohor area in southeastern Ashanti Belt of the Birimian, Ghana*
}

\author{
${ }^{1}$ G. M. Tetteh and ${ }^{2}$ E. Effisah-Otoo \\ ${ }^{1}$ University of Mines and Technology, P.O. Box 237, Tarkwa, Ghana \\ ${ }^{2}$ Golden Star Bogoso/Prestea Ltd, Bogoso
}

Tetteh, G. M. and Effisah-Otoo, E. (2017), "Petrography and Geochemistry of some Granitoids associated with Gold Mineralisation at Mpohor area in southeastern Ashanti Belt of the Birimian, Ghana", Ghana Mining Journal, Vol. 17, No. 1, pp. 31 - 42.

\begin{abstract}
Mpohor area in Western Region of Ghana is located within the Birimian at the southeastern corridor of Ashanti belt. Diamond drilling in the area which encloses Father Brown concession intersected steeply dipping igneous rocks on which petrographic and whole rock XRF analyses were conducted to describe the rock types according to mineralogy, texture, alteration and mode of mineralisation. The study showed that gabbro and diorite are weakly deformed, partially altered and of greenschist facies metamorphism. These rocks intruded into belt granitoids which accompanied metavolcanic rocks (well exposed at a coastal region to the southeast). Subsequent tonalite and granodiorite intrusives into sheared areas of gabbro are deformed with foliation being parallel to the major foliation in the host rock. This ductile deformation was accompanied by brittle deformation and infiltrated by hydrothermal fluids leading to silicification, carbonatisation, sericitisation, pyritisation of second and third generations and gold mineralisation. On the contrary, chloritisation with fine chalcopyrite together with pyrite of first generation characterise host gabbro and diorite. Hence deformed pyrite porphyroblast of second generation is found in tonalite and partly in contact with magnetite and also associated with gold. The ore zone (Au grade between 1.78 to $48.80 \mathrm{~g} / \mathrm{t})$ in tonalite is characterised with lower $\mathrm{TiO}_{2}$ content $(<0.73 \mathrm{wt} \%)$ in addition to $\mathrm{Fe} / \mathrm{Mg}$ ratio above 2.4 and $\mathrm{Zr}$ values less than $100 \mathrm{ppm}$ which may suggest that mineralised fluid was depleted of $\mathrm{Ti}$ and $\mathrm{Zr}$ and $\mathrm{Mg} / \mathrm{Fe}$ ratio above 2.4. These probably show that hydrothermal fluid which has the potential for high sulphide-Au mineralisation accompanied more mafic host rocks.
\end{abstract}

Keywords: Petrography, Geochemistry, Granitoids, Gold Mineralisation, Southeastern Ashanti belt

\section{Introduction}

Textural relationship of mineralised rocks may show widespread alteration types and zonation of orebody. For example areas which have been intensely altered may contain different mineral assemblages from intermediate or less altered zones. For gold deposition, there may be lack of vertical continuity due to zonation of the affected wall rocks during hydrothermal alteration. Thus gold carried in reduced sulphur complex fluids may form deposits associated with sulphides that were introduced during alteration (Groves et al., 1987). Geochemically, rocks with high $\mathrm{Fe} / \mathrm{Mg}$ ratios such as tholeiitic basalts and dolerites may show similar effects but other rocks which impede hydrothermal fluid circulation because they are impermeable to gold-bearing fluids may occur as deposits close to the contact between some sedimentary and volcanic sequences, as occurs in the Birimian, Canadian deposits and Kalgoorlie deposits in western Australia. Komatiites and some sulphidic interflow of sedimentary rocks have been identified as source rocks for gold but rarely are gold mineralisation linked to granitic sources (Mayer and Saag, 1985). Hence gold deposits in granites may be associated with metamorphic and tectonic conditions.
In the Birimian, syngenetic gold deposits have been linked with manganiferous, carbonaceous schists and strata-bound sulphides, pyritic cherts and siliceous tuffs while gold-bearing quartz veins found in basaltic and andesitic sequences are structurally controlled (Huot et al., 1987 and Leube et al., 1990). Associated alteration package to the epigenetic quartz veins are subordinate carbonates, green iron-bearing sericite and graphitic partings as well as disseminated sulphides which are hosted by metamorphosed volcanic and sedimentary units (Leube et al., 1990; Dzigbodi-Adjimah, 1993).

Unlike elsewhere in the Birimian where ore channels occur in metavolcanic rocks and metasedimentary units, the rocks at Mpohor area are intrusives. These granitoids lack the main features associated with primary lode gold and disseminated sulphides. Again the steeply-dipping, deeply penetrating and laterally extensive fault which is filled with carbonaceous material at the contact between the metasedimentary and metavolcanic rocks, which is typical of primary lode gold occurrence in the Birimian rocks on the Ashanti belt, is missing (Dzigbodi-Adjimah, 1988). Petrographic and geochemical studies were used to identify the different rocks, alteration types, mineral associations, and geochemical signatures of gold mineralisation at Mpohor area. 


\subsection{Location, Accessibility and Physiography}

Mpohor area in Western Region of Ghana is located approximately $15 \mathrm{~km}$ northwest of Takoradi harbour and $59 \mathrm{~km}$ southwest of Golden Star Wassa Mine plant site (Fig. 1). The concession covers an area of about $41.5 \mathrm{Km}^{2}$ with the boundaries lying between latitudes $5^{\circ} 03^{\prime} \mathrm{N}$ to $4^{\circ} 57^{\prime} \mathrm{N}$, and longitudes $1^{\circ} 53^{\prime} \mathrm{W}$ to $1^{\circ} 52^{\prime} \mathrm{W}$. The southern end of the property is accessible by partially tarred and gravelled road from Apowa on the Takoradi to Tarkwa highway. The road runs through Mpohor in the south to Adum-Banso in the north, continues through Benso Oil Palm Plantation (BOPP) and re-connects the Takoradi to Tarkwa highway at Bonsa.

The area has a relatively high topography, with relief ranging between $100 \mathrm{~m}$ to $300 \mathrm{~m}$ above Mean Sea Level, interspersed by undulating valleys with dense bamboo strands in many of the valleys. The area is drained by small tributaries of the Butre and Hwini Rivers. The main streams which flow into these rivers flow throughout the year whereas the tributaries flow mainly in the rainy season.

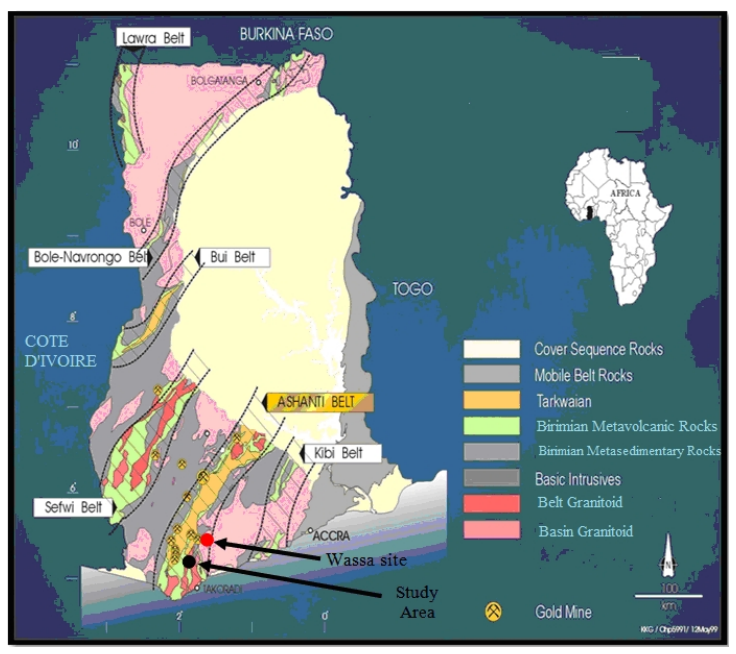

Fig. 1 Geological map of Ghana showing Gold belts and the study area (after, Leube $e t$ al., 1990)

\subsection{Regional Geology}

The Mpohor area falls within the Birimian domain of the West African Craton in Ghana. The Birimian Palaeoproterozoic terrane, also known as the Baoule-Mossi Domain, (Abouchami et al., 1990), outcrops in the southeastern portion of the ManShield of the West Africa Craton. It extends across the western half of Ghana, Côte D'Ivoire, southern Mali, Burkina Faso, Senegal and the west of Niger. Birimian rocks are made up of metasedimentary and metavolcanic rocks that have been metamorphosed to slates, phyllites, metagreywackes and metavolcanic rocks which are interbedded with metamorphosed pyroclastic members (Loh and Hirdes, 1999).

The metasedimentary rocks (formerly referred to as Lower Birimian) are regarded as "basin" deposits and are separated by "belt" deposits which are subparallel series of northeast trending volcanic rocks (formerly referred to as Upper Birimian) (Leube et al., 1990; Allibone et al., 2002a).

Though Trashliev (1972) and Asihene and Barning (1975) suggested a stratigraphic break between the metasedimentary and metavolcanic rocks, Leube et al. (1990) proposed a lateral facies between Birimian metavolcanic rocks and metasedimentary rocks which together make a supergroup that was deposited contemporaneously. They also believed that the metavolcanic rocks and metasedimentary rocks are related in origin. These put to rest an earlier controversy about the evolution of the Birimian rocks of Ghana where the Anglophone geologists were of the opinion that the metasedimentary rocks were older than the metavolcanic rocks but reversed by the Francophone geologists (Tagini, 1971; Papon, 1973; Bessoles, 1977 and Attoh, 1980). Leube et al. (1990) and Hirdes et al. (1993) based on plate tectonic concepts, regard the Birimian metasedimentary rocks as having evolved from volcanic island arcs and ridges within old Archaean sialic crust whilst the volcanic rocks were derived from contemporaneous igneous activity within volcanic belts that were located at the edges of the depositional basins. Milési et al. (1991) viewed the evolution of the Birimian as having formed from volcanic belts and sedimentary basins within the West African Craton and subsequent collision.

The metasedimentary rocks and metavolcanic rocks of the Birimian have been folded, metamorphosed and intruded by various granitic bodies grouped into basin and belt granitoids. The basin granitoids are post-Birimian and pre-Tarkwaian and were classified as G1 or Cape Coast granitoids. The belt granitoids are younger and commonly found within the volcanic belts and were referred to as Dixcove or G2 granitoids (Kesse, 1985; Leube et al., 1990). The belt granitoids occur in concordant batholiths accompanied by pegmatites and quartz veins (Kesse, 1985).

Tarkwaian rocks consist of coarse clastic sedimentary rocks that include conglomerates, arkoses, sandstones and minor shales. Pebbles in the conglomerates include volcanic and sedimentary clasts derived from the Birimian rocks and granitoids (Eisenlohr and Hirdes, 1992). The Tarkwaian rocks are commonly found in close proximity to Birimian volcanic rocks either in unconformable stratigraphic contact or as imbricated fault-bounded slices. 
The Birimian rocks host the world class Obuasi gold deposit of AngloGold Ashanti; the Prestea, Bogoso, Ayanfuri, Amansie, Konongo, Yamfo and Mpohor (Father Brown) gold deposits among others. Gold deposits in the Tarkwaian include mines at Abosso, Tarkwa, and Iduapriem.

The Ashanti belt is one of the Birimian volcanic belts in Ghana. The southern part of this belt is characterised by three volcanic sections, made up of metamorphosed basalt, andesite, pyroclastic and sedimentary rocks, with granite-diorite suites occupying intervening positions (Leube et al., 1990 and Dampare et al., 2008). Mafic-ultramafic bodies which also intrude this part of the volcanic belt and the largest mafic-ultramafic body has recently been interpreted as a Palaeoproterozoic ophiolite complex in the supra-subduction zone (Attoh et al., 2006).

The evolutionary history of the Birimian of southwestern Ghana indicates that the volcanic belts and sedimentary basins were developed during two separate orogenic cycles (Leube et al., 1990; Taylor et al., 1992; Davis et al., 1994; Oberthür et al., 1998; Allibone et al., 2002 a,b). The first orogenic cycle, the "Eburnean 1", occurred between $2240-2150 \mathrm{Ma}$, involved the eruption of Birimian volcanic rocks and intrusion of granitoid rocks which cut earlier volcanic rocks and an episode of metamorphism accompanied by an uplift and erosion. The second major orogeny, the "Eburnean 2" occurred between 2130-2088 Ma which deformed and metamorphosed both the Birimian and Tarkwaian rocks to lower greenschist facies (Allibone et al., 2002a). According to John et al. (1999), amphibolite facies metamorphism is found in proximity to granitoid intrusives. The regional pervasive NE-striking structural grain of Birimian and Tarkwaian rocks was established during the "Eburnian 2" orogeny (Allibone, et al., 2002a).

Primary gold of the Birimian occurs as lode or vein-type deposits emplaced within steeplydipping, deeply penetrating and laterally extensive fault zones which are commonly referred to as "fissure zones". These mineralised zones normally occur within a black lustrous carbonaceous material, loosely referred to as "graphite" and generally located at the contact between metaargillitic sedimentary rocks and tholeiitic basaltic rocks (Mücke and Dzigbodi-Adjimah, 1994).

Mineralisation associated with belt-basin contact includes Obuasi, Prestea, Bogoso, Konongo and Bibiani. Common mineralisation characteristics include deep-seated, and high-angle wrench faults. However cross-cutting northeast-southwest trending faults have also exerted an influence on deposits in these zones.
Various mineral paragenetic models have been proposed for the deposits along the Ashanti belt. Early workers on the Ashanti gold belt e.g. Cooper (1934) and Junner (1935) focused mainly on the visible minerals within the mineralised zones and considered gold to be younger because it is frequently included in pyrite and arsenopyrite.

Leube et al. (1990) grouped gold mineralisation on the Ashanti belt into two types; Quartz Vein Type (QVT) and Disseminated Sulphide Type (DST). These divisions broadly reflect the geology and mineral associations within the ore types. The QVT localised in deformed quartz veins of up to $5 \mathrm{~m}$ thick were considered to be epigenetic whereas the DST was regarded as syngenetic in origin with minor occurrence of epigenetic gold selvages of quartz veins.

Mücke and Dzigbodi-Adjimah (1994) observed ten parageneses in the ore at Prestea and Bogoso with four carbonate phases and two main phases of gold mineralisation - an initial "gold sulphide" phase and "gold sulphosalt-fahlore" phase. These two gold phases displayed unique mineral assemblages; "gold sulphide" comprises of pyrite, arsenopyrite, pyrrhotite, chalcopyrite and sphalerite and "gold sulphosalt-fahlore" consists of bournonite, tetrahydrite, aurostibnite, chalcopyrite and pyrite. Mumin et al. (1994) proposed that the differences between the "QVT and DST" as proposed by Leube et al. (1990) are partly due to differences in depth (corresponding to pressure and temperature variation) of mineralisation at Prestea and Bogoso respectively and that the ore at Prestea was formed at $11 \mathrm{~km}$ depth and that at Bogoso at $7 \mathrm{~km}$.

Oberthür et al. (1997) also recognised the bimodal occurrence of gold on the Ashanti belt at Obuasi, Prestea, Konongo and Bogoso and classified them as "quartz vein with free-milling gold" and "sulphide ores". This classification is associated with distinct mineral and elemental composition, thus the "quartz vein with free-milling gold" was associated with $\mathrm{Pb}, \mathrm{Cu}, \mathrm{Sb}$ and $\mathrm{Ag}$ sulphides and ores associated with $\mathrm{Fe}$ and As sulphides. There were however some fundamental disagreements between Oberthür et al. (1997) and Mumin et al. (1994) pertaining to the origin of the two main gold types and the remobilisation and re-precipitation of primary gold into coarse gold proposed by Mumin et al. (1994). Oberthür et al. (1997) concluded among others that the depth difference between the two deposits could not be supported by weathering and redistribution as re-precipitation of gold was not supported by gold distribution in arsenopyrite which demonstrated that most of the sulphide bound gold is still in place where it first crystallised.

Allibone et al. (2002a, 2002b and 2004) detailed the structures associated with gold mineralisation 
within the Birimian at Obuasi, Bogoso and Chirano and concluded that the relative timing of gold mineralisation at the three localities are similar and that the differences in hydrothermal mineral assemblages and metal associations between the deposits are most likely a reflection of fluid interaction into different host rocks.

The Mpohor area is located within the Birimian and at the southeastern corridor of Ashanti belt. The area encloses Father Brown and Adoikrom deposits. The deposits are located in an igneous intrusive rock known as the Mpohor Complex comprising of gabbro, diorite and granodiorite-tonalite. The ore body dips at about $40^{\circ}$ to the southwest, whilst that at Adoikrom dips at $60^{\circ}$ to the west with the main structure trending northwest to southeast. The mineralised zones are often defined by strong carbonate and sericite alterations with much fine grained disseminated sulphides. Sheared smoky to milky quartz veins with sulphides also characterise mineralised zones.

\section{Resources and Methods Used}

Samples for petrographic and geochemical studies were selected from Father Brown deposit in the area to give good representation of the different rock types mapped and logged in boreholes. Sampling was across the local strike of the main foliation in the rocks. All the samples were collected from oriented diamond drill core in fresh rocks in order to derive maximum information.

A total of twenty-eight (28) representative samples were taken across the deposit such that a minimum of eight samples occur in all the rock types taking into consideration the alteration and sulphide mineralisation. Hand specimen description was conducted on all the rocks and twenty-eight thin and polished sections from fresh rock samples were investigated in transmitted and reflected light microscopy to determine the petrographical characteristics at the Geological Engineering Laboratory at University of Mines and Technology (UMaT), Tarkwa.

Preparations of thin sections were carried out according to the procedure outlined in Hutchison (1974) and studied using the SM Lux Leitz microscope. Minerals were identified using their colour, texture, pleochroism, bireflectance, and anisotropy. Mineral abbreviations used were after Whitney and Evans (2010). Modal percentages were by point counting.

Polished sections were prepared for the identification and characterisation of the opaque phases in the samples and their textural relationships using SM Lux Leitz microscope with Canon camera attached. Mineral identification and textural relationships were aided by Picot et al.
(1982) and Spry and Gedlinske (1987). The modal percentages were normalised and plotted on QAP diagram (Streckeisen, 1974).

Twenty (20) representative samples which were examined in thin and polished sections were selected from hanging wall through the ore zone into the footwall for geochemical analysis. Standard procedures were followed during preparation of samples for whole-rock geochemical analysis at Associated Laboratory Services (ALS) in Canada. The samples were weighed and crushed to about $70 \%$ below $2 \mathrm{~mm}$ and subsequently split using the riffle splitter and pulverised and split to $85 \%$ to pass through $<75 \mu \mathrm{m}$. Powdered samples were obtained by mechanical crushing and pulverisation using an agate mortar. Whole rock major element analysis was performed on fused discs by automated XRF-06 at Associated Laboratory Services, Canada. The specimens were prepared using $50 \%$ lithium tetraborate $\left(\mathrm{Li}_{2} \mathrm{~B}_{4} \mathrm{O}_{7}\right)$ and $50 \%$ lithium borate $\left(\mathrm{LiBO}_{2}\right)$. A calcined or ignited sample $(0.9 \mathrm{~g})$ was added to $9.0 \mathrm{~g}$ of lithium borate flux $\left(50 \%-50 \% \mathrm{Li}_{2} \mathrm{~B}_{4} \mathrm{O}_{7}-\mathrm{LiBO}_{2}\right)$, mixed well and fused in an auto fluxer between 1050 $1100^{\circ} \mathrm{C}$. A flat molten glass disc was prepared from the resulting melt. This disc was then analysed by $\mathrm{X}$-ray fluorescence spectrometry. The upper detection limit is $100 \%$ and lower detection limit is $0.01 \%$.

Specimens were prepared using hydrofluoric (HF) acid, nitric acid $\left(\mathrm{HNO}_{3}\right)$ and perchloric acid $\left(\mathrm{HClO}_{4}\right)$ digestion and hydrochloric acid $(\mathrm{HCl})$ leach. A prepared specimen $(0.25 \mathrm{~g})$ was digested with perchloric, nitric, hydrofluoric and hydrochloric acids. The residue was topped up with dilute hydrochloric acid and analysed by inductively coupled plasma-atomic emission spectrometry (ICP-AES). Following this analysis, the results were reviewed for high concentrations of bismuth, mercury, molybdenum, silver and tungsten and diluted accordingly. Samples meeting this criteria were then analysed by inductively coupled plasma-mass spectrometry (ICP-MS). Results were corrected for spectral inter-element interferences. Standard reference samples were used in the quantitative analyses of the elements. Details of the analytical procedure, accuracy, precision and standards are available at the Associated Laboratory Services (ALS) Minerals, Canada. The lower detection limits (in ppm) for the minor and trace elements are $10.0(\mathrm{Cr}, \mathrm{P}), 5.0(\mathrm{Cu}$, $\mathrm{Mn}$ ), 0.5 (Ba, Ce, Co, La, Pb), 0.2 (As, Cu, Li, Ni, $\mathrm{Sn}, \mathrm{Sr}, \mathrm{Cd}$ ), 0.1 (Hf, Nb, Rb, Sc), 0.05 (Dy, Gd, Be, $\mathrm{Cs}, \mathrm{Ga}, \mathrm{Ge}, \mathrm{Mo}$ ), 0.03 (Er, Eu), 0.02 (Re), 0.01 (Ho, Ag, Bi), and 0.005 (In). 


\section{Results and Discussions}

\subsection{Diorite}

This rock occurs at the hanging wall (FD45/01), footwall (e.g. FD47/11, FD47/12) and rarely encountered in the ore zone (FD47/08) (Fig. 2). The ore zone is delineated at the contact between granodiorite and tonalite The rock is greenish grey to dark grey, massive, medium to coarse grained and with porphyritic texture and visible amphibole, pyroxene, plagioclase, alkali feldspar, quartz, chlorite and disseminated sulphides.

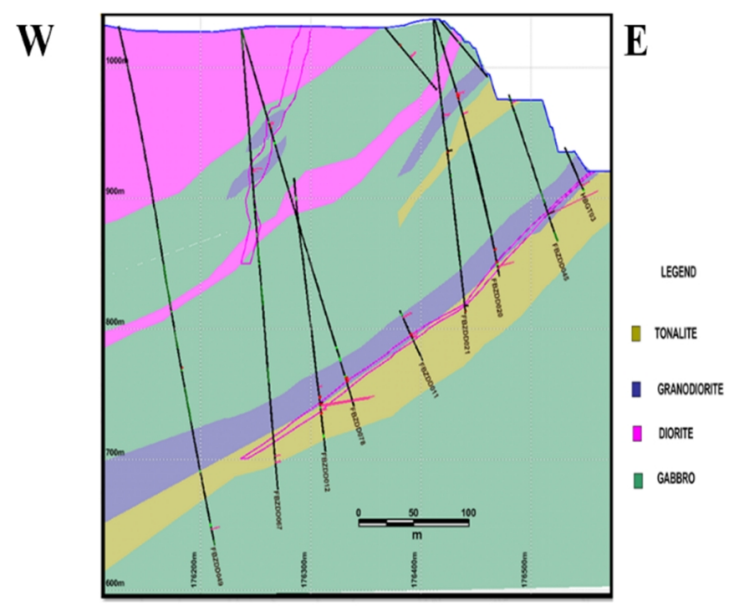

Fig. 2 A Vertical Drill Section 33025N

In thin section, the rock is medium to coarse grained and sub-ophitic. Modal percentages of the minerals are shown in Table 1. Amphibole is coarse grained, prismatic with its margins destroyed by plagioclase. It also has quartz inclusions, pleochroic from green to dark green and partially altered to fine tabular dark green chlorite and fine granular epidote which shows second order colours of yellow and blue. Pyroxene is strongly pleochroic to dark green. It shows strong birefringence and partially altered to fine granular epidote. Fine platy chlorite and granular epidote are probably alteration products of pyroxene and amphibole and also shows granular texture with partial alteration of primary minerals (Fig. 3a). Plagioclase is euhedral to subhedral, medium to coarse grained and clouded with alteration minerals of sericite and quartz. It shows albite and calsbad twining with extinction angles of $9^{\circ}$ and $15^{\circ}$ respectively. These extinction angles are typical of oligoclase-andesine composition $\left(\mathrm{An}_{27}-\mathrm{An}_{33}\right)$ (Fig. $3 b)$.

Ore minerals identified in this rock are pyrite, chalcopyrite and magnetite. Pale yellow and isotropic, anhedral porhyroblastic pyrite 2 occurs with gangue minerals and magnetite at footwall in plane polarised light (Fig. 3c). Late pyrite 3 is coarse grained and subhedral with magnetite inclusions.

Magnetite 2 is an anhedral prophyroblast which is grey and isotropic. It is in close contact with pyrite 2. Elsewhere magnetite 1 is deformed and is partially in contact with gangue. Bright yellow, isolated, anhedral chalcopyrite with weak anisotropism is in close contact with magnetite and gangue (Fig. 3c). Early anhedral pyrite 1 is in close contact with magnetite and gangue minerals but pseudomorphs are preserved at the hanging wall (Fig. 3d).
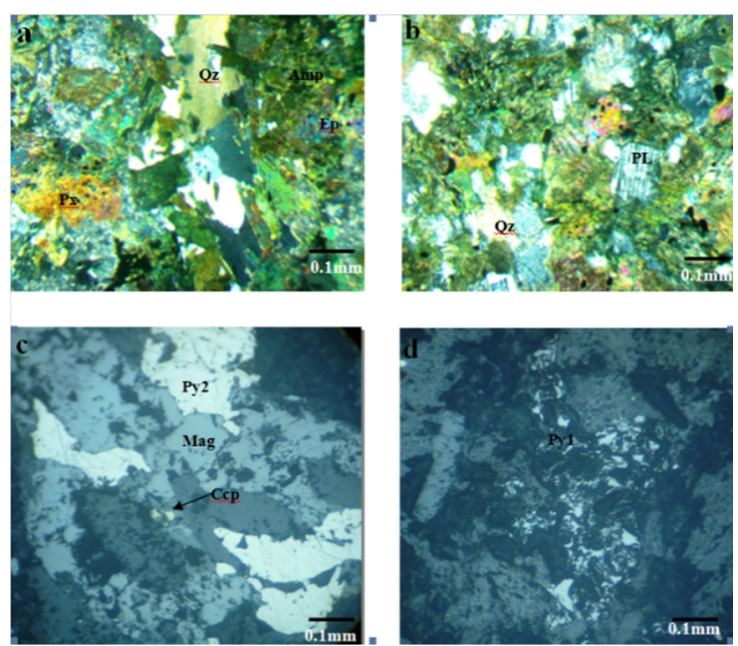

Fig. 3 Photomicrograph of Diorite in a-b) thin section under Crossed Nicols c-d) in polished section under Plane Polarised Light

\subsection{Gabbro}

This rock normally occurs at the footwall (e.g. FD45/05, FD46/33, and FD58/29) and hanging wall (e.g. FD46/30). It is dark grey, massive, medium to coarse grained, porphyritc, slightly deformed and fractured.

In thin section, the rock is coarse grained and weakly foliated. Modal percentage of the rock is shown in Table 2.

Plagioclase is medium to coarse grained and strongly altered to sericite and quartz. Relict albite twining occurs with extinction angle of $25^{\circ}$. Weakly altered variety of plagioclase which occurs at the margin of amphibole and pyroxene has extinction angle of $22^{\circ}$ typical of andesine $\left(\mathrm{An}_{22}\right)$. It is clouded with alteration products of amphibole. Plagioclase occurs also as inclusion in pyroxene and shows relict albite twining with extinction angle of $15^{\circ}$. Amphibole shows characteristic cleavage at $56^{\circ}$ and strongly pleochroic from dark green to brown with inclusions of plagioclase (Fig. $4 a)$. 
Amphibole is significantly altered to epidote and chlorite (Fig. 4b). Pyroxene occurs as subhedral, short prismatic, weakly pleochroic brown to dark brown and partially altered to epidote. Secondary quartz which may occur along fractures and cleavages in amphibole and as inclusion in pyroxene is clouded with opaque minerals, shows wavy extinction or recrystallised (Fig. 4b). Chlorite is dark brown, typical of magnesium chlorite, which is suggestive of a breakdown product of magnesium-rich mineral (pyroxene?).

Pale yellow, granoblastic to subhedral pyrite 2 is moderately deformed with magnetite 1 and gangue inclusion. In reflected light under plane polarised light, it is isotropic and occurs in alteration halos of the ferromagnesian minerals (Fig. 4c). Other portions of the polished section show highly deformed, anhedral porphyroblastic pyrite 1 which is partially associated with gangue minerals (Fig. 4d). Dark grey, granular magnetite 1 which is isotropic is partially in contact with gangue and also occurs as inclusion in Pyrite 2.
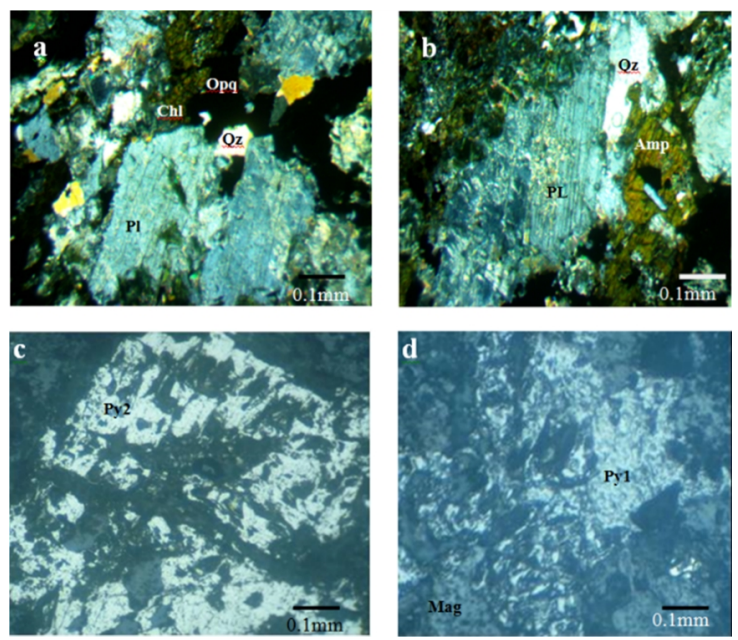

Fig. 4 Photomicrograph of Gabbro at Footwall in a-b) thin section under Crossed Nicols c-d) polished section under Plane Polarised Light

\subsection{Tonalite}

This rock occurs in the ore zone (e.g. FD45/03, FD46/31, and FD46/32), partly at the footwall (e.g. FD45/06, FD45/07) and in hanging wall (e.g. FD53/13, FD58/25). The rock is light grey, fine to medium grained, porphyritic, moderately sheared and weakly foliated. It is composed of quartz, potassium feldspar, plagioclase, amphibole and chlorite and also characterised by strong to moderate disseminated sulphide and carbonate (e.g. FD47/10, FD46/31, and FD46/32). Feldspar and quartz phenocrysts are common.

Microscopically, the rock is medium to coarse grained and moderately foliated.
Table 1 Modal percentage of Diorite at Mpohor area

\begin{tabular}{|l|c|c|c|c|}
\hline & \multicolumn{4}{|c|}{ Sample ID } \\
\hline $\begin{array}{c}\text { Sample } \\
\text { Location }\end{array}$ & HW & HW & OZ & FW \\
\hline \multicolumn{1}{|c|}{ Minerals } & FD47/12 & FD47/11 & FD47/08 & FD45/01 \\
\hline Amphibole & 45 & 10 & - & 75 \\
\hline Plagioclase & 28 & 45 & 43 & 15 \\
\hline Pyroxene & 2 & 33 & 3 & 5 \\
\hline Microcline & - & 2 & - & - \\
\hline Quartz & 3 & 2 & 5 & 2 \\
\hline Sericite & 1 & - & - & - \\
\hline Calcite & - & - & - & 3 \\
\hline Carbonate & - & - & 4 & \\
\hline Chlorite & 1 & - & 35 & \\
\hline Epidote & $<1$ & 5 & - & \\
\hline Pyrite & 15 & 2 & 8 & $<1$ \\
\hline Magnetite & 5 & 1 & 2 & \\
\hline Chalcopyrite & $<1$ & $<1$ & - & \\
\hline Total & 100 & 100 & 100 & 100 \\
\hline
\end{tabular}

$\mathrm{HW}=$ Hanging Wall, $\mathrm{FW}=$ Footwall, and $\mathrm{OZ}=$ Ore Zone

It is composed of plagioclase, quartz, altered amphibole, muscovite, microcline and carbonates. Modal percentage of the rock is shown in Table 3.

Plagioclase is coarse grained and partially altered. It is highly clouded with alteration and opaque minerals. Plagioclase shows relict albite twining with extinction angle of $5^{\circ}$ which suggests that it is oligoclase $\left(\mathrm{An}_{17}-\mathrm{An}_{25}\right)$. Elsewhere, plagioclase is highly altered to sericite. Quartz is coarse grained with margins destroyed by plagioclase (Figs. 5a,b). It is highly clouded with epidote and ore minerals and shows wavy extinction. Amphibole is fine grained and highly altered to yellowish brown chlorite (magnesium chlorite) and dark granular epidote. Muscovite defines foliation (Fig. 5b). Carbonate is tabular, fine grained and shows twinkling. It is dispersed within the rock.

Tonalite which occurs within the ore zone is characterised by higher percentage of anhedral pyrite $(1 \%$ to $11 \%)$. Pale yellow moderately deformed, pyrite 2 is associated with gold (Figs. $5 \mathrm{c}, \mathrm{d})$. Pyrite 2 has gangue inclusions and is isotropic. Late pyrite 3 occurs as coarse aggregate of subhedral to euhedral overgrowths with magnetite and quartz inclusions. Gold is bright yellow and occurs as sub-granular anhedral and disseminated within pyrite 2 . It occurs as an inclusion in deformed fine to medium grained quartz and isotropic (Fig. 5d). In the footwall and hanging wall, moderately deformed porphyroblast of pyrite 1 is partially to completely replaced by gangue. 

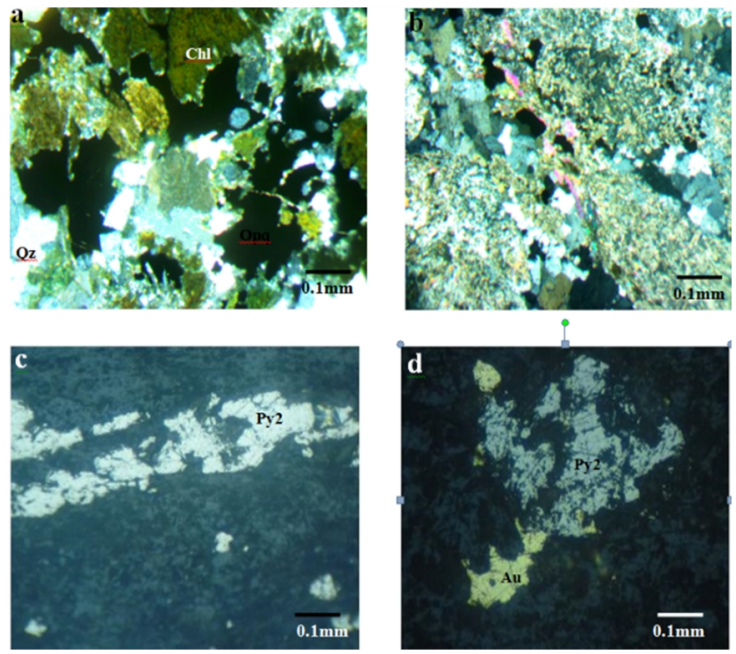

Fig. 5 Photomicrograph of Tonalite in a-b) thin section at Hanging Wall under Crossed Nicols c-d) polished section in Ore Zone under Plane Polarised Light

Table 2 Modal percentage of Gabbro at Mpohor area

\begin{tabular}{|l|l|l|l|l|}
\hline \multicolumn{5}{|l|}{ Sample ID } \\
\hline $\begin{array}{l}\text { Sample } \\
\text { Location }\end{array}$ & HW & HW & FW & HW \\
\hline Minerals & FD45/05 & FD46/33 & FD46/30 & FD58/29 \\
\hline Plagioclase & 55 & 50 & 60 & 50 \\
\hline Amphibole & 30 & 10 & 15 & 10 \\
\hline Pyroxene & 8 & 38 & - & 37 \\
\hline Epidote & 3 & - & 4 & - \\
\hline Chlorite & 2 & - & 18 & - \\
\hline Quartz & 2 & 2 & 2 & 2 \\
\hline Pyrite & $<1$ & $<1$ & 1 & $<1$ \\
\hline Magnetite & $<1$ & $<1$ & $<1$ & 1 \\
\hline Total & 100 & 100 & 100 & 100 \\
\hline
\end{tabular}

\subsection{Granodiorite}

This rock occurs at the ore zone. It is light grey, fine to medium grained, strongly to moderately foliated. It is composed of feldspar, quartz, and chlorite and has strong disseminated sulphides with carbonate alteration as it reacts with dilute hydrochloric acid. Microscopically, this rock is coarse grained, sheared and foliated with a cataclastic texture (Fig. 6a). It is composed of sericitised plagioclase, quartz, K-feldspar (microcline), muscovite and chlorite. The modal percentage is shown in Table 4.

Plagioclase is medium grained and partially altered to sericite and quartz. It is colourless and shows relict albite twining with extinction angle of $10^{\circ}$ of oligoclase composition $\left(\mathrm{An}_{12}-\mathrm{An}_{28}\right)$. Some quartz grains are recrystallised into fine and medium grains with general characteristic undulose extinction. Amphibole is fine grained and highly altered. It is pleochroic from light brown to brown with strong alteration along cleavages into epidote and chlorite (Figs. 6 a,b).

Pale yellow and isotropic, anhedral pyrite 2 is moderately deformed and in close contact at the margins with gangue mineral. Late pyrite 3 occurs as coarse aggregate of subhedral overgrowths with magnetite inclusion (Fig. 6c). Pyrite 3 also is partially in close contact at its margins with gangue mineral. It has sub-rounded magnetite inclusions (Fig. 6d).
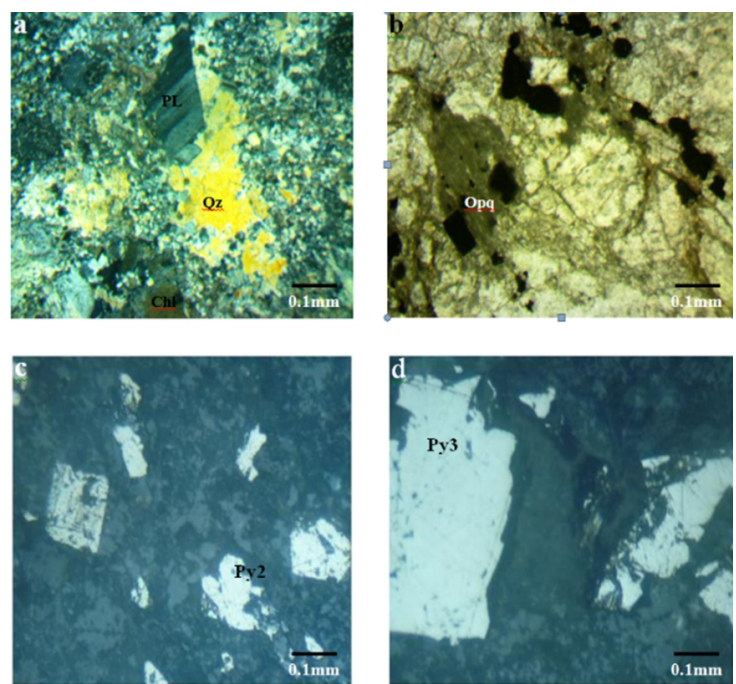

Fig. 6 Photomicrograph of thin section of

Granodiorite at Ore Zone under a)

Crossed Nicols b) Plane Polarised Light cd) Polished section under Plane Polarised Light

This rock occurs in the ore zone. It is smoky to milky and crystalline and may be foliated or fractured. The rock is composed of mainly quartz and feldspars

In hand specimen, quartz is partially in contact with calcite and sulphides which may be associated with visible gold. In thin section, this rock is medium to coarse grained and fractured. It is strongly foliated and composed of quartz, plagioclase, muscovite, carbonate, and pyrite. Modal percentages of the minerals are shown in Table 5.

Plagioclase is coarse grained and partially altered. It shows relict albite twining with extinction angle of $7^{\circ}$ of oligoclase composition $\left(\mathrm{An}_{18}\right)$. Coarse grained quartz is deformed, elongated and shows wavy extinction.

Anhedral pyrite 2 is slightly deformed and elongated. It is partly in association with late quartz at its margins and has sub-rounded magnetite inclusions (Fig. 7c). 
Table 3 Modal percentage of Tonalite in Ore Zone at Mpohor area

\begin{tabular}{|c|c|c|c|c|c|c|c|c|c|c|c|c|c|c|c|}
\hline \multicolumn{16}{|c|}{ Sample ID } \\
\hline \multicolumn{16}{|l|}{ Sample } \\
\hline Location & 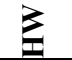 & ڤิ & O & ऽิ & $\vec{z}$ & ல & ऽิ & 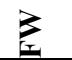 & ऽ & $\sum_{\Sigma}$ & 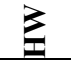 & $\vec{I}$ & తి & $\widehat{o}$ & ปै \\
\hline Minerals & $\underset{n}{\stackrel{m}{a}}$ & 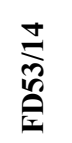 & 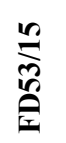 & $\underset{n}{\stackrel{0}{e}}$ & $\underset{n}{\stackrel{n}{a}}$ & 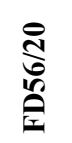 & 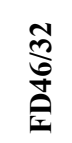 & $\begin{array}{l}\stackrel{\wp}{8} \\
\stackrel{n}{7} \\
\stackrel{0}{0}\end{array}$ & 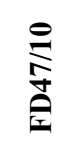 & 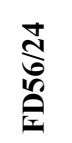 & 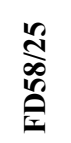 & 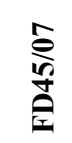 & 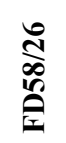 & 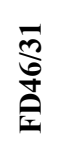 & 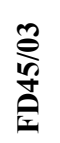 \\
\hline Plagioclase & 55 & 55 & 55 & 53 & 47 & 55 & 40 & 60 & 40 & 35 & 35 & 60 & 55 & 30 & 50 \\
\hline Quartz & 35 & 38 & 35 & 35 & 38 & 35 & 25 & 34 & 20 & 15 & 45 & 35 & 40 & 15 & 40 \\
\hline Sericite & - & - & - & - & - & - & 14 & - & - & - & - & - & - & - & - \\
\hline Microcline & 2 & - & - & - & - & - & - & - & - & 6 & - & - & 3 & - & - \\
\hline Amphibole & 6 & - & - & - & - & 7 & - & - & - & 42 & - & 5 & - & - & - \\
\hline Chlorite & - & 5 & 7 & 8 & 10 & - & 3 & 3 & 25 & 2 & 2 & - & - & 45 & 5 \\
\hline Epidote & 1 & 2 & 2 & 1 & 5 & 2 & 1 & - & 3 & - & - & - & - & - & - \\
\hline Muscovite & - & - & - & 2 & - & - & - & - & $<1$ & - & 10 & - & - & - & - \\
\hline Carbonate & - & - & - & - & - & - & 5 & 2 & $<1$ & - & 3 & $<1$ & 2 & 5 & 2 \\
\hline Pyrite & 1 & $<1$ & 1 & 1 & $<1$ & 1 & 11 & 1 & 11 & $<1$ & 5 & $<1$ & $<1$ & 5 & 3 \\
\hline Gold & - & - & $<1$ & - & - & - & - & - & - & - & - & - & - & $<1$ & $<1$ \\
\hline Magnetite & $<1$ & $<1$ & $<1$ & $<1$ & $<1$ & $<1$ & 1 & $<1$ & 1 & $<1$ & $<1$ & $<1$ & $<1$ & $<1$ & $<1$ \\
\hline Total & 100 & 100 & 100 & 100 & 100 & 100 & 100 & 100 & 100 & 100 & 100 & 100 & 100 & 100 & 100 \\
\hline
\end{tabular}

$\mathrm{HW}=$ Hanging Wall, $\mathrm{FW}=$ Footwall, and $\mathrm{OZ}=$ Ore Zone

Table 4 Modal percentage of Granodiorite in the Ore Zone at Mpohor area

\begin{tabular}{|l|c|c|}
\hline \multicolumn{1}{|c|}{ Minerals } & \multicolumn{2}{c|}{ Sample ID } \\
\hline & FD56/19 & FD58/28 \\
\hline Plagioclase & 46 & 45 \\
\hline Quartz & 44 & 30 \\
\hline Amphibole & - & 15 \\
\hline Microcline & 5 & 5 \\
\hline Pyrite & 5 & 5 \\
\hline Magnetite & $<1$ & $<1$ \\
\hline Total & 100 & 100 \\
\hline
\end{tabular}

\subsection{Major Elements Geochemistry}

Major oxide compositions of the Mpohor area rocks are provided in Table 6. Apart from a highly silicified sample (FD46/31) with $\mathrm{SiO}_{2}$ of $86.26 \mathrm{wt}$ $\%$, tonalite in the ore zone with gold grade variation from 1.78 to $48.80 \mathrm{~g} / \mathrm{t}$ analyse major oxides in wt \% as $\mathrm{SiO}_{2}(44.00-63.61), \mathrm{Al}_{2} \mathrm{O}_{3}$ (14.15 - 16.77), $\mathrm{Fe}_{2} \mathrm{O}_{3}$ (3.48 - 14.16), $\mathrm{CaO}$ (4.01 8.12), $\mathrm{MgO}\left(1.49\right.$ - 2.86), $\mathrm{Na}_{2} \mathrm{O}\left(2.73\right.$ - 5.63), $\mathrm{K}_{2} \mathrm{O}$ (1.47 - 2.56), $\mathrm{Cr}_{2} \mathrm{O}_{3}(0.01), \mathrm{TiO}_{2}(0.32$ - 2.12), $\mathrm{MnO}(0.07-0.29), \mathrm{P}_{2} \mathrm{O}_{5}(0.11-0.12)$. Some trace elements recorded in the ore zone in $\mathrm{ppm}$ are Co (9.30 - 41.70), Cr (40.0 - 60.0), Th (0.82 - 2.18), U (0.43 - 1.09), W (1.00 - 5.83), Y (10.00 - 17.50), $\mathrm{Yb}(0.90$ - 1.51), Zr (32.00 - 117.00).

Generally, no significant variation occurs in the major oxide composition of the rocks. However, lower $\mathrm{TiO}_{2}$ content $(<0.73 \mathrm{wt} \%), \mathrm{Zr}$ less than
$100 \mathrm{ppm}$ characterise the ore as lower values of $\mathrm{Mg} / \mathrm{Fe}$ ratio are associated with gabbro in both hanging wall and footwall (Figs. 8 to 10).

\subsection{Gold Mineralisation as related to Petrography and Geochemistry}

Petrographic studies on the rocks at Mpoho area showed that gabbro and diorite occur at the hanging wall and footwall of the ore zone (Fig. 2). These intrusives cut belt granitoids accompanied deposition of mafic volcanic rocks (exposed at the coast, southwest of the deposit). These were followed by later intrusions of granodiorite and tonalite (Attoh et al., 2006).

Amphibole and pyroxene in the gabbro and diorite are partially altered to chlorite and epidote with plagioclase altered to sericite, fine quartz and carbonate (Figs. 3a,b, 4a,b). Tonalite and granodiorite are parallel intrusives into sheared zone of gabbro with the ore zone at the contact area of these two granitoids emplaced such that granodiorite is in proximity to the hanging wall while tonalite occurs closer to the footwall (Fig. 2). Metamorphism in the Birimian including the "belt type" granitoids is generally up to greenschist facies (Debon and Le Fort, 1983; Kesse, 1985; Leube et al., 1990; Flach, 1999). Considering the observation by John et al. (1999) that higher metamorphism to amphibolite facies may occur in proximity to intrusives, no such observation was made in the Mpohor area. Ductile deformation which resulted into alignment of minerals and recrystallisation of quartz was accompanied by 
cataclastic deformation with brittle textures at granodiorite-tonalite contact, filled by auriferous quartz veins with subordinate $\mathrm{Mg}$-carbonates. In the tonalite, there are partial alterations of amphibole and plagioclase to chlorite and sericite plus fine grained quartz respectively (Fig. 5b). Similar textures are exhibited by granodiorite (Figs. 6a,b). Quartz granitoid is a coarse grained quartzofeldspathic rock which is foliated and fractured in the ore zone (Figs. 7a,b).

The distribution of ore minerals in gabbro shows that pyrite 1 occurs in alteration halos of the ferromagnesian minerals as highly deformed, anhedral porphyroblast which is partially to completely in contact with magnetite and gangue minerals (Fig. 4d). In tonalite in ore zone, sheared pyrite 2 is associated with disseminated gold (Figs. $5 \mathrm{c}, \mathrm{d})$. Pyrite 2 in granodiorite has inclusions of magnetite which elsewhere is stretched along weak foliation. Pyrite 3 is subhedral and is rarely overprinted by gangue or alteration minerals (Figs. $6 \mathrm{c}, \mathrm{d})$. In the quartz granitoid, pyrite 2 which is sheared parallel to main foliation contains magnetite inclusions which are also sheared along an earlier foliation in the rock (Fig. 7c).

Generally no significant variation occurs in the major oxide composition of the rocks. Lower $\mathrm{TiO}_{2}$ content $(<0.73$ wt $\%)$ characterise the ore and may be inherent to the later intrusives as $\mathrm{Ti}$ is relatively an immobile element (Fig. 8). Also lower values of $\mathrm{Mg} / \mathrm{Fe}$ ratio are associated with gabbro in both hanging wall and footwall with the ore showing higher values (Fig. 9). Hence Fe-chlorite introduced during metamorphism and alteration in the non-mineralised zone may be over-ridden by $\mathrm{Mg}$-chlorite in the ore zone (1.78 to $48.80 \mathrm{~g} / \mathrm{t}$ ) which corresponds with $\mathrm{Fe} / \mathrm{Mg}$ ratio above 2.4 (Table 6, Fig. 9). Lower $\mathrm{Mg} / \mathrm{Fe}$ ratio $(<\sim 5.0)$ is associated with gabbro in both hanging wall and footwall whilst $\mathrm{Mg} / \mathrm{Fe}$ ratio above 5.0 characterise mineralisation (Fig. 9).

Though Manu (1993) reported that both Mg- and $\mathrm{Fe}$ - rich chlorites in the foliations of metasedimentary and metavolcanic rocks in the Birimian were hydrothermal, Mg-chloritisation favoured hydrothermal alteration in the mineralised tonalite intrusive at Mpohor area. In addition, $\mathrm{Zr}$ values less than $100 \mathrm{ppm}$ characterise the mineralised zone in tonalite (Fig. 10). Considering that zircon is found in all rock types mostly associated with igneous and metamorphic rocks, lower $\mathrm{Zr}$ value recorded in the ore at Mpohor area is suggestive that the mineralised fluid was depleted of Zr.

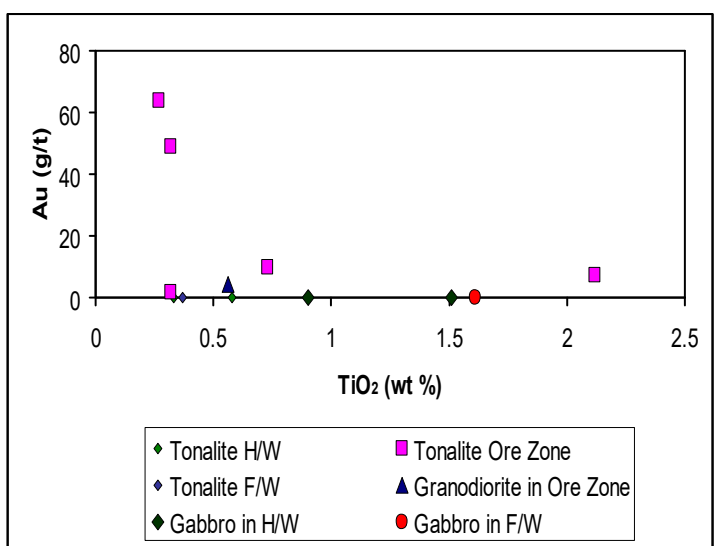

Fig. 8 Au grade against $\mathrm{TiO}_{2}$ in rocks at Mpohor area showing generally lower values of $\mathrm{TiO}_{2}$ in the Ore

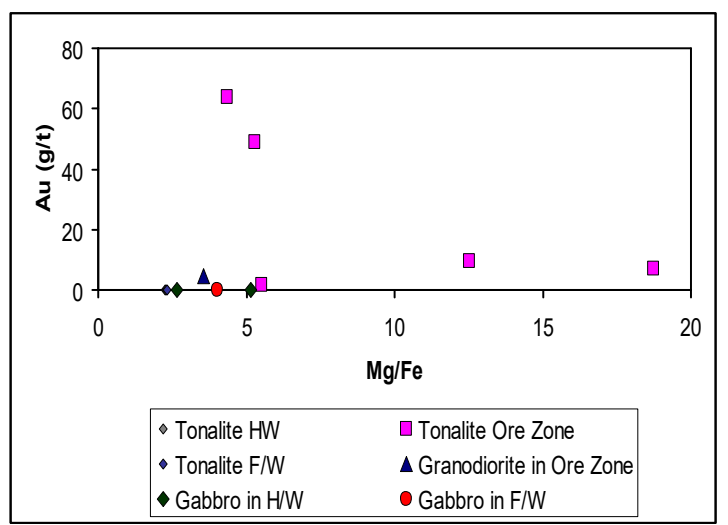

Fig. 9 Au grade against $\mathrm{Mg} / \mathrm{Fe}$ ratio in rocks at Mpohor area showing Ore in Tonalite having higher $\mathrm{Mg} / \mathrm{Fe}$ ratios

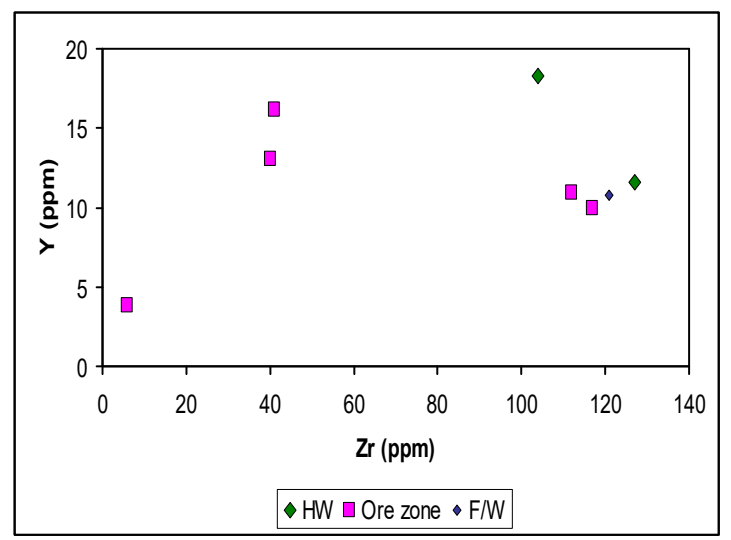

Fig. $10 \mathrm{Y}$ against $\mathrm{Zr}$ in Tonalite at Mpohor area showing lower $\mathrm{Zr}$ content in Ore Zone 
Table 6 Whole rock XRF composition and Au values of representative samples from Mpohor area

\begin{tabular}{|c|c|c|c|c|c|c|c|c|c|c|c|c|}
\hline \multirow{2}{*}{\begin{tabular}{|c|} 
Oample ID \\
Oxide wt \% \\
\end{tabular}} & FD53/13 & FD58/25 & FD46/31 & FD46/32 & FD47/10 & FD53/16 & FD45/03 & FD53/17 & FD58/28 & FD46/33 & FD58/29 & FD46/30 \\
\hline & \multicolumn{2}{|c|}{ Tonalite $\mathrm{H} / \mathrm{W}$} & \multicolumn{5}{|c|}{\begin{tabular}{|c|} 
Tonalite Ore Zone \\
\end{tabular}} & \multicolumn{2}{|c|}{ Tonalite F/W } & \multicolumn{2}{|c|}{ Gabbro H/W } & $\mathbf{F} / \mathbf{W}$ \\
\hline $\mathrm{SiO}_{2}$ & 66.57 & 52.74 & 86.26 & 44.00 & 46.18 & 63.61 & 62.45 & 65.35 & 45.68 & 49.48 & 51.82 & 49.78 \\
\hline $\mathrm{Al}_{2} \mathrm{O}_{3}$ & 15.63 & 14.05 & 3.36 & 16.73 & 16.77 & 15.04 & 14.50 & 15.67 & 14.15 & 15.86 & 15.36 & 15.29 \\
\hline $\mathrm{Fe}_{2} \mathrm{O}_{3}$ & 3.85 & 6.49 & 3.60 & 9.17 & 14.16 & 3.66 & 3.48 & 3.81 & 10.29 & 14.77 & 13.07 & 15.44 \\
\hline $\mathrm{CaO}$ & 3.89 & 8.98 & 1.78 & 6.59 & 6.84 & 4.01 & 4.56 & 3.46 & 8.12 & 7.73 & 8.43 & 7.11 \\
\hline MgO & 1.70 & 2.85 & 0.48 & 2.63 & 2.46 & 1.53 & 1.49 & 1.64 & 2.89 & 2.87 & 4.93 & 3.83 \\
\hline $\mathrm{Na}_{2} \mathrm{O}$ & 4.79 & 0.54 & 1.61 & 4.81 & 4.11 & 4.97 & 5.63 & 4.78 & 2.73 & 3.55 & 3.29 & 3.08 \\
\hline $\mathrm{K}_{\mathbf{2}} \mathrm{O}$ & 1.98 & 3.36 & 0.12 & 2.56 & 1.47 & 1.92 & 1.61 & 1.93 & 2.41 & 0.51 & 0.60 & 0.55 \\
\hline $\mathrm{Cr}_{2} \mathrm{O}_{3}$ & 0.01 & 0.01 & 0.01 & 0.01 & 0.01 & 0.01 & 0.01 & 0.01 & 0.01 & 0.01 & 0.01 & 0.01 \\
\hline $\mathrm{TiO}_{2}$ & 0.33 & 0.58 & 0.27 & 0.73 & 2.12 & 0.32 & 0.32 & 0.37 & 0.56 & 1.51 & 0.90 & 1.61 \\
\hline MnO & 0.08 & 0.08 & 0.04 & 0.18 & 0.17 & 0.07 & 0.08 & 0.07 & 0.29 & 0.23 & 0.24 & 0.28 \\
\hline $\mathbf{P}_{\mathbf{2}} \mathbf{O}_{5}$ & 0.12 & 0.10 & 0.18 & 0.28 & 0.40 & 0.11 & 0.11 & 0.12 & 0.27 & 0.53 & 0.11 & 0.66 \\
\hline SrO & 0.11 & $<0.01$ & $<0.01$ & 0.06 & 0.02 & 0.06 & 0.10 & 0.12 & 0.02 & 0.03 & $<0.01$ & 0.01 \\
\hline $\mathrm{BaO}$ & 0.11 & 0.09 & 0.02 & 0.08 & 0.09 & 0.09 & 0.09 & 0.12 & 0.09 & 0.04 & 0.04 & 0.04 \\
\hline LOI & 0.58 & 9.92 & 1.93 & 8.67 & 4.91 & 4.62 & 5.33 & 2.22 & 10.50 & 2.66 & 0.88 & 2.14 \\
\hline Total & 100.05 & 99.98 & 100.05 & 96.69 & 99.92 & 100.30 & 100.05 & 99.96 & 98.22 & 100.00 & 99.91 & 100.05 \\
\hline \multicolumn{13}{|c|}{ Elements (ppm) } \\
\hline Ba & 887 & 665 & 40.3 & 585 & 776 & 725 & 661 & 942 & 763 & 262 & 252 & 228 \\
\hline $\mathrm{Ce}$ & 34.7 & 27.8 & 7.3 & 25.9 & 20.9 & 32.1 & 31 & 33.7 & 20.2 & 24.3 & 22.2 & 29.6 \\
\hline Co & 10.3 & 34.5 & 7.4 & 23.8 & 41.7 & 9.3 & 10.1 & 9.9 & 16.4 & 37.3 & 43.1 & 37.3 \\
\hline $\mathrm{Cr}$ & 50 & 60 & 30 & 50 & 50 & 50 & 40 & 50 & 60 & 20 & 90 & 10 \\
\hline Cs & 1.16 & 2.75 & 0.06 & 0.92 & 0.98 & 1.13 & 0.61 & 1.8 & 1.8 & 0.33 & 0.85 & 0.64 \\
\hline Dy & 1.76 & 2.9 & 0.78 & 3.03 & 2.15 & 1.63 & 1.58 & 1.67 & 2.8 & 3.61 & 3.55 & 4.49 \\
\hline $\mathrm{Er}$ & 1.08 & 1.81 & 0.39 & 1.72 & 1.29 & 1.01 & 0.98 & 1.06 & 1.74 & 2.03 & 2.26 & 2.47 \\
\hline Eu & 0.92 & 1.01 & 0.46 & 1.47 & 1.77 & 0.78 & 0.83 & 0.89 & 1.51 & 2.06 & 1.68 & 2.19 \\
\hline Ga & 21.8 & 18.2 & 4.1 & 19.4 & 22.9 & 20.5 & 18.2 & 22.1 & 17.5 & 20.4 & 18.6 & 19.2 \\
\hline Gd & 2.55 & 3.37 & 1.16 & 3.32 & 2.78 & 2.25 & 2.38 & 2.49 & 3.42 & 4.26 & 3.9 & 5.06 \\
\hline Hf & 3.6 & 3 & 0.3 & 1.4 & 1.2 & 3.2 & 3.2 & 3.3 & 1.1 & 3.5 & 2 & 1.7 \\
\hline Ho & 0.39 & 0.63 & 0.15 & 0.63 & 0.46 & 0.35 & 0.33 & 0.36 & 0.62 & 0.75 & 0.77 & 0.9 \\
\hline La & 16 & 12.1 & 3 & 11.8 & 9.1 & 14.5 & 14.1 & 15.2 & 8.6 & 10.7 & 8.2 & 12.2 \\
\hline Lu & 0.18 & 0.27 & 0.05 & 0.21 & 0.17 & 0.17 & 0.16 & 0.17 & 0.27 & 0.27 & 0.34 & 0.33 \\
\hline Mo & $<2$ & $<2$ & 7 & $<2$ & $<2$ & $<2$ & $<2$ & $<2$ & $<2$ & 2 & $<2$ & $<2$ \\
\hline $\mathbf{N b}$ & 4.7 & 6 & 0.8 & 2.5 & 3.6 & 4.7 & 4.1 & 4.6 & 1.4 & 2.8 & 2.8 & 2.6 \\
\hline Nd & 16.1 & 13.1 & 4.5 & 14.8 & 11.2 & 14.6 & 14.1 & 15.6 & 11.6 & 15.4 & 13.7 & 19.1 \\
\hline Pr & 4.19 & 3.42 & 0.97 & 3.34 & 2.67 & 3.85 & 3.69 & 4.1 & 2.67 & 3.24 & 3.11 & 4.02 \\
\hline $\mathbf{R b}$ & 51.7 & 165 & 3.6 & 67.1 & 38.7 & 52.9 & 41.8 & 61.4 & 75.8 & 12.8 & 15.1 & 16.5 \\
\hline Sm & 2.92 & 2.8 & 1.07 & 3.33 & 2.34 & 2.56 & 2.58 & 2.81 & 2.66 & 3.83 & 3.16 & 4.55 \\
\hline Sn & $<1$ & $<1$ & $<1$ & 1 & $<1$ & $<1$ & $<1$ & $<1$ & $<1$ & 1 & $<1$ & 1 \\
\hline Sr & 959 & 112.5 & 124 & 775 & 589 & 657 & 869 & 1035 & 542 & 648 & 431 & 494 \\
\hline $\mathrm{Ta}$ & 0.3 & 0.6 & $<0.1$ & 0.1 & 0.3 & 0.4 & 0.3 & 0.3 & 0.1 & 0.2 & 0.2 & 0.2 \\
\hline Tb & 0.36 & 0.54 & 0.14 & 0.49 & 0.4 & 0.32 & 0.32 & 0.34 & 0.52 & 0.59 & 0.64 & 0.73 \\
\hline Th & 2.64 & 1.86 & 0.22 & 0.82 & 1.04 & 2.18 & 1.49 & 1.73 & 1.14 & 0.75 & 0.59 & 0.79 \\
\hline TI & $<0.5$ & 0.7 & $<0.5$ & $<0.5$ & $<0.5$ & $<0.5$ & $<0.5$ & $<0.5$ & $<0.5$ & $<0.5$ & $<0.5$ & $<0.5$ \\
\hline $\mathrm{Tm}$ & 0.16 & 0.25 & 0.05 & 0.25 & 0.16 & 0.14 & 0.13 & 0.14 & 0.24 & 0.26 & 0.31 & 0.34 \\
\hline$u$ & 1.22 & 0.99 & 0.2 & 0.47 & 0.43 & 1.09 & 0.65 & 0.85 & 0.53 & 0.39 & 0.27 & 0.37 \\
\hline $\mathbf{v}$ & 81 & 131 & 14 & 91 & 215 & 75 & 66 & 87 & 89 & 138 & 158 & 123 \\
\hline w & $<1$ & 5 & 14 & 15 & 1 & 13 & 11 & 1 & 15 & $<1$ & $<1$ & $<1$ \\
\hline $\mathbf{Y}$ & 11.6 & 18.3 & 3.8 & 16.2 & 13.1 & 10.9 & 10 & 10.8 & 17.5 & 18.5 & 21.8 & 23.1 \\
\hline Yb & 1.02 & 1.58 & 0.31 & 1.51 & 1 & 0.93 & 0.9 & 0.94 & 1.47 & 1.72 & 1.96 & 2.02 \\
\hline $\mathrm{Zr}$ & 127 & 104 & 6 & 41 & 40 & 112 & 117 & 121 & 32 & 144 & 63 & 58 \\
\hline $\mathrm{Au}(\mathrm{g} / \mathrm{t})$ & $<0.01$ & 0.01 & 64.01 & 9.65 & 7.23 & 1.78 & 48.8 & $<0.01$ & 4.44 & $<0.01$ & 0.01 & $<0.01$ \\
\hline
\end{tabular}

\section{Conclusions}

Mpohor area, located within the Birimian at the southeastern part of Ashanti belt has gabbro and diorite which are weakly deformed and of greenschist facies, hence they are referred to as meta-gabbro and meta-diorite. These rocks have primary amphibole and pyroxene partially altered to chlorite, epidote, albite with minor magnetite, chalcopyrite and pyrite. Tonalite and granodiorite intruded into a zone which is already sheared such that continuous deformation led to the intrusives becoming parallel to the major foliation in the host rocks.

Chloritisation, dominant at the hanging wall and footwall, was accompanied by brittle and ductile deformations at the contact between granodiorite and tonalite. These week zones served as pathways for infiltrated hydrothermal fluids leading to silicification, carbonatisation, sericitisation and pyritisation (of three generations of which the second generation of pyrite is associated with gold mineralisation). Fine chalcopyrite together with pyrite of first generation (pyrite 1) which occurs as highly deformed, anhedral porphyroblast are partially associated with magnetite in diorite and gabbro. An earlier deformation which probably preceded granitoid emplacement is preserved as alignment of magnetite inclusions.

Generally no significant variation occurs in the major oxide composition of mineralised from nonmineralised rocks. Lower $\mathrm{TiO}_{2}$ content $(<0.73 \mathrm{wt}$ $\%$ ) in addition to lower $\mathrm{Zr}$ values (less than 100 ppm) characterise the ore probably due to depletion of $\mathrm{Ti}$ and $\mathrm{Zr}$ in tonalite. Lower $\mathrm{Mg} / \mathrm{Fe}$ ratio $(<\sim 5.0)$ is associated with gabbro in both hanging wall and footwall whilst $\mathrm{Mg} / \mathrm{Fe}$ ratio above 5.0 characterise 
the mineralised zone. These characteristics of gold mineralisation have not been reported in the Ashanti belt.

\section{References}

Abouchami, W., Boher, M., Michard, A., Albarede, F. (1990), "A major 2.1 Ga Event of Mantle Magmatism in West Africa, an Early Stage Crustal Accretion" Geophysical Research Bulletin, Vol. 95, pp. 17605 - 17629.

Allibone, A., McCuaig T. C., Harris D., Etheridge, M., Munroe, S., Byrne, D. (2002a), "Structural Controls on Gold Mineralisation at the Ashanti Gold Deposit Obuasi, Ghana", Economic Geology, Special Publication, Vol. 9, pp. $60-$ 94.

Allibone, A., Teasdale, J., Cameron, G., Etheridge, M., Uttley, P., Soboh, A., Appiah-Kubi, J., Adanu, A., Arthur, R., Mamphey, J., Odoom, B., Zuta J., Tsikata, A., Pataye, F. and Famiyeh, S. and Lamb, E. (2002b), "Timing and Structural Controls on Gold Mineralisation at the Bogoso Gold Mine, Ghana, West Africa" Economic Geology, Vol. 97, pp. 949 - 969.

Allibone, A. H., Hayden, P., Cameron, G. and Duku, F. (2004), "Palaeoproterozoic Gold Deposits Hosted by Albite and Carbonate Altered Tonalite in the Chirano District, Ghana, West Africa", Society Economic Geology, Vol. 99, pp. 479 - 497.

Asihene, K. A. B. and Barning, K. (1975), A Contribution to the Stratigraphy of the Birimian System of Ghana, West Africa, Ghana Geological Survey Report 75/5, Accra, 30 pp.

Attoh, K. (1980), "Structure, Stratigraphy, and some Chemical characteristics of an Early Proterozoic (Birimian) Volcanic belt, northeastern Ghana", Current Research, Part C, Geological Survey Canada Paper 80-1C, pp. 69 -80 .

Attoh, K., Evans, M. J. and Bickford, M. E. (2006), "Geochemistry of an Ultramafic-Rodingite Rock Association in the Palaeoproterozoic Dixcove Greenstone Belt Southwestern Ghana", Journal of African Earth Sciences, pp. 333 346.

Bessoles, B. (1977), Géologie de l'Afrique, Vol. 1, Le Craton Ouest Africain Mémoire. Bureau Recherque Géologique Minière, Orléans. 88, $402 \mathrm{pp}$.

Cooper, W. G. G. (1934), "The Geology of the Prestea Goldfield", Gold Coast Geological Survey, Memoir 3, 20 pp.

Dampare, S. B., Shibata, T., Asiedu, D. K., Osae, S. and Banoeng-Yakubo, B. (2008), "Geochemistry of Palaeoproterozoic Metavolcanic Rocks from the Southern Ashanti Volcanic Belt, Ghana, Petrogenetic and Tectonic Setting Implications", Precambrian Research, 162, pp. $403-423$.
Davis, D., Hirdes, W., Schaltegger, E. and Nunoo, E. A. (1994), "U/Pb Age Constrains on Deposition and Provenance of Birimian and Gold Bearing Tarkwaian Sediments in Ghana West Africa", Precambrian Research, Vol. 67, pp. 89 - 107.

Debon, F. and Le Fort, P. (1983), "A Chemical and Mineralogical Classification of Common Plutonic Rocks and Associations", Transactions of the Royal Society of Edinburgh, Earth Sciences, Vol. 73: pp.135 - 149.

Dzigbodi-Adjimah, K. (1988), "The Genesis of the Birimian Gold Deposits of Ghana", International Conference on the Geology of Ghana, Accra, Ghana, $9^{\text {th }}-16^{\text {th }}$ October, pp. 123 $-167$.

Dzigbodi-Adjimah, K. (1993), “Geology and Geochemical Patterns of Birimian Gold Deposits, Ghana West Africa", Journal of Geochemical Exploration, Vol. 47, pp. 305 320.

Eisenlohr, B. N. and Hirdes, W. (1992), "The Structural Development of the Early Proterozoic Birimian and Tarkwaian Rocks of Southwest Ghana, West Africa", Journal of African Earth Sciences, Vol. 14, 3, pp. 313 - 325.

Flach, G. A. (1999), "Terminal Exploration Report Hwini-Butre Concession", Ave Delta Press, pp. 43 - 106.

Groves, D. I., Phillips, N., Ho, S. E., Houstoun, S. M. and Standing, C. A. (1987), "Craton-Scale Distribution of Archaean Greenstone Gold Deposits: Predictive capacity of the Metamorphic Model", Economic Geology, Vol. 82, pp. 2045 - 2058.

Hirdes, W., Senger, R., Adjei, J., Efa, Loh, G. and Tettey, A. (1993), "Explanatory Notes for the Geological Map Southwestern Ghana 1:100000", Geolosches Jarbuuch, Hanover Press, B83, 139 pp.

Huot, D., Sattran, V. and Zida, P. (1987), "Gold in Birrimian Greenstone Belts of Burkina Faso, West Africa", Economic Geology, Vol. 82, pp. 2033 - 2044.

Hutchison, C. S. (1974), Laboratory Handbook of Petrographic Techniques, John Wiley and Sons Press, 527 pp.

John, T., Kleimd, R., Hirdes, W. and Loh, G. (1999), "The Metamorphic Evolution of the Palaeoproterozoic (Birimian) Volcanic Ashanti belt (Ghana, West Africa)" Precambrian Research, Vol. 98, pp. 11 - 30.

Junner, R. N. (1935), "Gold in the Gold Coast", Gold Coast Geological Survey Memoir 4, 67 pp.

Kesse, G. O. (1985), The Mineral and Rock Resources of Ghana, A. A Balkema, Rotterdam, $610 \mathrm{pp}$.

Leube, A., Hirdes, W., Mauer, R., Kesse, G. O. (1990), "The Early Proterozoic Birimian Supergroup of Ghana and Some Aspects of its Associated Gold Mineralisation", Precambrian Research, Vol. 46, pp. 136 - 165. 
Loh, G. and Hirdes, W. (1999), "Explanation notes for the Geological Map of Southwest Ghana 1:100000 sheet Sekondi (0402A) and Axim (0403B)", Geological Survey Bulletin, No. 49, BGR, Hannover, 149 pp.

Manu, J. (1993), "Gold Deposits of Birimian Greenstone Belt in Ghana: Hydrothermal Alteration and thermodynamics", Braunschweiger Geologisch-Paläontologische Dissertationen, 17, 116 S., 44 abb. 14 Tab. 185 pp.

Mayer, M. and Saag, R. (1985), "The Gold content of some Archaen rocks and their possible relationship to Epigenetic Gold-quartz Vein Deposits", Mineralium Deposita, Vol. 20, pp. 284 - 289.

Milési, J. P., Ledru, P., Ankrah, P., Johan, V., Marcoux, E., Vinchon, Ch. (1991), "The Metallogenic Relationship between Birimian and Tarkwaian Gold Deposits in Ghana", Mineralium Deposita Conference, Vol. 26 pp. $228-238$.

Mücke, A. and Dzigbodi-Adjimah, K. (1994), "Ore texture and parageneses of the Prestea and Obuasi Gold deposits in the Ashanti belt of Ghana, An Ore Microscopic Study", Geologisches, Jahrbuch, Vol. D100, pp. 167 199.

Mumin, A. H., Fleet, M. E. and Longstaffe, F. J. (1994), "Gold Mineralisation in As-rich Mesothermal fluids in the Ashanti Gold belt, Ghana: Stable Isotope Geochemistry of Carbonates, Graphite and Quartz", Economic Geology, Vol. 31, pp. 135 - 148.

Oberthür, T., Vetter, U., Davis, D.W. and Amanor, J. A. (1998), "Age constraints on gold mineralisation and Palaeoproterozoic Crustal Evolution in the Ashanti belt of southern Ghana", Precambrian Research, Vol. 80, pp. $129-143$.

Oberthür, T., Weiser, T., Amanor, J. A. and Chryssoulis, S. L. (1997), "Mineralogical siting and Distribution of Gold in Quartz Veins and Sulphide Ores of the Ashanti Mine and other Deposits in the Ashanti Belt of Ghana: Genetic Implications", Mineralium Deposita, Vol. 32, pp. 2 - 15.

Papon, A. (1973), "Géologie et Minéralisations du Sud-Ouest de la Côte d'Ivoire', Mémoire Bureau Recherque Géologique Minière, France, 80, 284 pp.

Picot, P. and Johan, Z. (1982), Atlas of Ore Minerals, Elsevier, Amsterdam, Adams Press, $275 \mathrm{pp}$.

Streckeisen, A. (1974), “Classification and Nomenclature of Plutonic Rocks, Recommendation of the IUGS Subcommission on Systematics of Igneous Rocks", Geologische Rundschau. Internationale Zeitschrift fur Geologie, Stuttgart, Vol. 63, pp. 773 - 785.

Spry, P. G., Gedlinske, B. L. (1987), Tables for the Determination of Opaque Common Minerals,
The Economic Geology Publishing Company, $52 \mathrm{pp}$.

Tagini, B. (1971), “Esquisse structurale de la Côte d'Ivoire, Essai de Géotechnique Régionale", Thèse Université Lausanne, SODEMI, Republique de Côte d'Ivoire, 302 pp.

Taylor, P. N., Moorbath, S., Leube, A. and Hirdes, W. (1992), "Early Proterozoic Crustal Evolution in the Birimian of Ghana Constraints from Geochronology and Isotope Geology", Precambrian Research, Vol. 56, pp. 97 - 111.

Trashliev, S. S. (1972), "The Geology of $1 / 4^{\circ}$ Field Sheets No. 82 and 46, Wiawso, S. E. and Asangragwa, N. E", Unpublished Report of the Ghana Geological Survey, $88 \mathrm{pp}$.

Whitney, D. L. and Evans, B. W. (2010), "Abbreviations for Names of Rock-Forming Minerals", American Mineralogist, Vol. 95, pp. $185-187$.

\section{Authors}

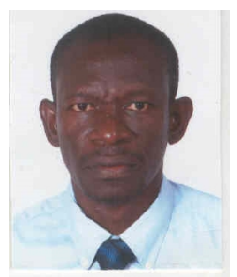

G. M. Tetteh obtained degrees in BSc, (Hons.) Geology with Physics in 1988, MPhil in Structural Geology in 1995 and $\mathrm{PhD}$ in Mineralisation and Geochemistry in 2010 from the University of Ghana. He previously worked as gold exploration geologist in the Birimian terrains from 1995 to 2001. Currently a lecturer at the Department of Geological Engineering, University of Mines and Technology (UMaT), Tarkwa. His areas of specialisation are Petrology, Structural Geology, Geochemistry and Mineral Exploration. George is a member of Ghana Institution of Geoscientists and Geological Society of Africa.

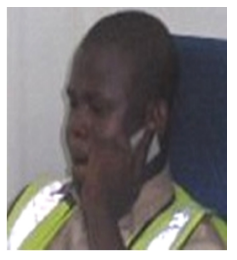

E. Effisah-Otoo obtained Diploma in Geological Engineering from Tarkwa School of Mines in June 2001. He has worked in the capacity of Project Exploration/Production Geologist at Golden Star Bogoso/Prestea, Huni-Butre and Wassa Projects from 2002 to 2015. He obtained MSc Geological Engineering from University of Mines and Technology (UMaT), Tarkwa in June 2014. 